\title{
Gambaran Histologi Ren Tikus Putih (Rattus norvegicus L.) Hiperglikemia Setelah Pemberian Ekstrak Etanol Daun Mimba (Azadirachta Indica A. Juss)
}

\section{Histological Overview of Hyperglycemia White Rat (Rattus norvegicus L.) Kidneys After Treated by Ethanolic Neem (Azadirachta indica A. Juss) Leaf Extract}

\author{
Fani Fahriyansyah, Sri Isdadiyanto, Siti Muflichatun Mardiati Agung Janika Sitasiwi \\ Program Studi Biologi, Fakultas Sains dan Matematika, Universitas Diponegoro \\ Jl. Prof. Soedarto, SH, Tembalang, Semarang 50275, Indonesia \\ *Email: fanifahri6@gmail.com
}

Diterima 15 Juli 2021 / Disetujui 16 Agustus 2021

\begin{abstract}
ABSTRAK
Diabetes melitus merupakan penyakit kelainan metabolic yang ditandai dengan hiperglikemia kronis yang disebabkan tidak cukupnya produksi insulin dan resistensi insulin. Diabetes telah diketahui dapat menyebabkan komplikasi berupa kerusakan pada jaringan ginjal. Mimba (Azadirachta indica A.Juss) memiliki kandungan antioksidan flavonoid yang mampu menangkal radikal bebas dan memperbaiki jaringan ginjal yang rusak akibat diabetes. Penelitian ini menggunakan 18 tikus putih yang menjadi 6 kelompok perlakuan. P0 (kontrol normal) merupakan tukus normal diberi aquades. P1(Kontrol negatif) merupakan tikus hiperglikemia diberi aquades. P2 (kontrol positif) merupakan tikus hiperglikemia diberi glibenklamid dosis $2,25 \mathrm{mg} / \mathrm{kg}$ BB. P3, P4, dan P5 merupakan tikus hiperglikemia yang diberi ekstrak etanol daun mimba dosis 100, 200, dan $400 \mathrm{mg} / \mathrm{kg} \mathrm{BB}$. Data penelitian kemudian dianalisis dengan uji Anova. Untuk data yang tidak terdistribusi normal diuji dengan uji Kruskal-Wallis. Hasil menunjukkan bahwa pemberian ekstrak etanol daun mimba tidak memberikan pengaruh nyata terhadap bobot ginjal, konsumsi air minum, diameter glomerulus, ruang kapsula bowman, tebal sel epitel tubulus proksimal, dan tebal sel epitel tubulus distal. Kesimpulan dari penelitian ini adalah ekstrak etanol daun mimba mampu melindungi jaringan ginjal tikus putih dari paparan hiperglikemia.
\end{abstract}

Kata kunci : diabetes, glomerulus, kapsula bowman, tublus proksimal, tubulus distal

\begin{abstract}
Diabetes is a metabolic disorder that treats chronic hyperglycemia caused by insufficient insulin production and insulin resistance. Diabetes has been known to cause complications in the form of damage to kidney tissue. Neem (Azadirachta indica A.Juss) has flavonoid antioxidants that can ward off free radicals and repair kidney tissue damaged by diabetes. The purpose of the study was to examine the ethanol extract of neem leaves repairing kidney tissue. The study used 18 albino rats were divided into 6 treatment groups. P1 (negative control) was a hyperglycemic rats group were given distilled water. P2 (positive control) was a hyperglycemic rats were given $2.25 \mathrm{mg} / \mathrm{kg} \mathrm{BW}$ of glibenclamide. P3, P4, and P5 were rats were given 100, 200 , and $400 \mathrm{mg} / \mathrm{kg} \mathrm{BW}$ of ethanolic neem leaf extract The research data were analyzed by ANOVA. The non-normally distributed data were analyzed by Kruskal-Wallis. The results showed that the ethanol extract of neem leaves had no significant effect on kidney weight, water consumption, glomerular diameter, bowman's capsule space, proximal tubular epithelial cell thickness, and distal tubular epithelial cell thickness. The conclusion of this study was the ethanol extract of neem leaves was able to protect the kidney tissue of white rats from hyperglycemia.
\end{abstract}

Keywords : diabetes, glomerulus, bowman capsule, proximal tubule, distal tubule 


\section{PENDAHULUAN}

Diabetes melitus merupakan penyakit gangguan metabolik menahun akibat pankreas tidak memproduksi cukup insulin atau tubuh tidak dapat menggunakan insulin yang diproduksi secara efektif karena sel- sel target gagal atau tidak mampu merespon insulin secara normal (Kemenkes RI, 2014). Insulin berfungsi untuk homeostatis kadar glukosa darah yang diintegrasikan dengan metabolisme karbohidrat, protein, dan lemak. Kehilangan kepekaan terhadap insulin atau yang disebut juga dengan resistensi insulin berpengaruh terhadap hati,otot, dan jaringan adipose serta metabolisme dari glukosa dan lipid (Petrie et al., 2017).Laporan dari International Diabetes Federation (IDF) 2017, memprediksi adanya kenaikan jumlah penderita DM di dunia dari 425 juta jiwa pada tahun 2017, menjadi 629 juta jiwa pada tahun 2045. Diabetes melitus tidak hanya menyebabkan hiperglikemia namun juga menyebabkan komplikasi. Komplikasi yang dapat dialami oleh penderita Diabetes adalah Nefropati diabetik (Sugiarta \& Darmita, 2020).

Penelitian yang dilakukan oleh Arini dkk., (2020) menunjukkan bahwa ekstrak etanol daun mimba mampu memperbaiki jaringan ginjal pada tikus putih. Senyawa golongan terpenoid, flavonoid, alkaloid, saponin, tanin, asam lemak, steroid dan triterpenoid telah diketahui sebagai senyawa yang terkandung di dalam daun mimba (Aslam et al., 2009). Flavonoid, terutama quercetin telah diketahui memiliki aktivitas antidiabetik. Vessal et al., (2003) melaporkan bahwa quercetin mampu meregenerasi pulau langerhan pankreas dan meningkatkan sekresi insulin pada penderita diabetes yang diinduksi streptozotocin. Senyawa yang terdapat dalam daun mimba seperti flavonoid (quercetin) memiliki aktivitas antioksidan (Bandyopadhyay et al., 2002), sehingga tanaman ini dapat menghambat peroksidasi lipid dengan cara membersihkan radikal bebas dan meningkatkan konsentrasi glutathione intraseluler (Ezz Din et al., 2011).

Penelitian ini penting untuk mengetahui efektifitas ekstrak daun mimba dalam memperbaiki histologi ren pada penderita diabetes melalui percobaan pada hewan coba. Penelitian ini untuk membuktikan bahwa daun mimba berpotensi melindungi jaringan ginjal tikus putih diabetes sehingga nantinya daun mimba dapat dijadikan sebagai obat alternatif untuk terapi penyakit diabetes. Indikator keberhasilan dari penelitian ini dapat dilihat dari bobot ginjal, konsumsi air minum, diameter glomerulus, jarak ruang kapsula bowman, tebal sel epitel tubulus proksimal, dan tebal sel epitel tubulus distal.

\section{METODE PENELITIAN}

Penelitian ini telah diperiksa oleh Komisi Etik Penelitian Kesehatan (KEPK) Fakultas Kedokteran Universitas Diponegoro Semarang dengan No. 101/EC/H/FK-UNDIP/X/2020. Penelitian dilakukan di Laboratorium Biologi Struktur dan Fungsi Hewan, Departemen Biologi, Fakultas Sains dan Matematika, universitas Diponegoro. Ekstrak etanol daun mimba dibuat di Laboratorium Terpadu, Universitas Diponegoro. Pembuatan preparat histopatologi dilakukan di Fakultas Kedokteran, Universitas Jendral Soedirman. Pengamatan preparat histologi dilakukam di Laboratorium Kesehatan Hewan, Semarang.

\section{Pembuatan Ekstrak Etanol Daun Mimba}

Daun mimba dikumpulkan dari lingkungan sekitar Universitas Diponegoro. Daun mimba diambil dari pohonnya, kemudian ambil bagian anak daunnya saja pada nodus ke-4 sampai 20, lalu dipisahkan tangkainya. Daun dicuci dengan menggunakan air mengalir kemudian dikering anginkan selama 12 jam. Daun mimba yang sudah kering dimasukkan ke dalam oven selama 3 hari dengan suhu $45^{\circ} \mathrm{C}$ untuk menghilangkan kadar air di dalamnya. Daun mimba yang sudah kering kemudian dihaluskan dengan blender. Serbuk daun lalu diekstraksi dengan menggunakan pelarut etanol.

\section{Hewan Uji}

Penelitian ini menggunakan hewan coba berupa tikus putih (Rattus norvegicus L.). Kriteria tikus putih yang digunakan adalah berjenis kelamin jantan, berasal dari Strain wistar, berumur 
2-3 bulan, bobot 200-300 g, dengan kondisi yang sehat. Tikus putih diinduksi dengan aloksan dosis $120 \mathrm{mg} / \mathrm{kg}$ BB secara intraperitonial supaya tikus putih menderita Hiperglikemia. Tikus yang telah mengalami hiperglikemia kemudian dibagi menjadi 5 kelompok perlakuan, dan 3 tikus yang tidak diinduksi aloksan menjadi kelompok kontrol. Kelompok perlakuan terdiri dari kelompok P0 (kontrol normal, tikus normal diberi aquades), P1 (kontrol negatif, tikus hiperglikemia diberi aquades), P2 (kontrol positif, tikus hiperglikemia diberi glibenklamid), P3 (tikus hiperglikemia diberi ekstrak etanol daun mimba $100 \mathrm{mg} / \mathrm{kg} \mathrm{BB}$ ), P4 (tikus hiperglikemia diberi ekstrak etanol daun mimba $200 \mathrm{mg} / \mathrm{kg} \quad \mathrm{BB}$ ), dan P5 (tikus hiperglikemia diberi ekstrak etanol daun mimba $400 \mathrm{mg} / \mathrm{kg} \mathrm{BB}$ ).

\section{Perlakuan Hewan Uji}

Tikus yang telah diinduksi aloksan (120 $\mathrm{mg} / \mathrm{kg} \mathrm{BB}$ ) melalui intraperitonial kemudian diberi perlakuan ekstrak etanol daun mimba yang telah dilarutkan dalam aquades sebanyak $2 \mathrm{ml}$ untuk tiap dosisnya secara per oral dengan menggunakan jarum gavage dengan lama waktu pemberian perlakuan adalah 27 hari.

\section{Pembuatan Preparat Histologi}

Organ yang telah difiksasi dibuat preparat histologi dengan metode parafin. Pembuatan preparat menggunakan automatic tissue processor. Jaringan didehidrasi menggunakan etanol bertingkat dari konsentrasi tinggi ke konsentrasi rendah. Jaringan yang telah di dehidrasi kemudian dilakukan proses clearing dengan menggunakan xylol. Jaringan kemudian diinfiltrasi dengan menggunakan parafin cair (Chong et al., 2012). Jaringan yang telah diinfiltrasi menggunakan parafin cair kemudian dilakukan embedding. Jaringan yang telah diembeding lalu di potong dengan menggunakan mikrotom dan pita hasil potongan direkatkan pada gelas benda. Jaringan yang telah melekat kemudian dilakukan pewarnaan (staining) dengan pewarna hematoxylin dan eosin. Tahap terakhir adalah mounting yakni proses penutupan jaringan dengan menggunakan kaca penutup (Zulfadhli dkk., 2016).

\section{Pengamatan Histologi}

Preparat histologi kemudian diamati dengan menggunakan fotomikrograf Leyca dengan perbesaran 100 dan 400 kali. Parameter histologi yang diamati adalah diameter glomerulus, lebar ruang kapsula bowman, tebal sel epitel tubulus proksimal, dan tebal sel epitel tubulus distal. Pengukuran diameter glomerulus dilakukan dengan mengukur diameter terlebar dan diameter tersempit kemudian dijumlah dan dibagi dua. Pengukuran jarak ruang kapsula bowman dilakukan dengan mengukur pada tepi glomerulus sampai dengan tepi kapsula bowman. Pengukuran tebal sel epitel tubulus proksimal dan distal diukur dari bagian tepi luar sampai ke dalam sel tubulus.

\section{Analisis Data}

Data hasil penelitian diuji normalitasnya dan homogenitasnya. Data hasil penelitian yang terdistribusi normal dan homogen dianalisis dengan menggunakan ANOVA. Sedangkan data yang tidak terdistribusi normal dan dan tidak homogen dianalisis dengan uji non parametrik Kruskal-Wallis. Analisis data menggunakan software SPSS 23.

\section{HASIL DAN PEMBAHASAN}

Berdasarkan pengamatan makroanatomi ginjal pada Gambar 1. dapat dilihat bahwa tidak ada perubahan yang signifikan baik dari bentuk, warna, dan ukuran dari ginjal tikus pada tiap-tiap perlakuan. Hal ini berarti pemberian ekstrak etanol daun mimba tidak memberikan perubahan terhadap makroanatomi ginjal. Bentuk penampakan ginjal tikus pada penelitian kali ini nampak berwarna coklat kemerahan dengan bentuk seperti kacang. Snell (2006) menyatakan bahwa penampakan warna ginjal nampak berwarna coklat kemerahan seperti kacang merah. Ceriana dan Sari (2016) menjelaskan bahwa warna ginjal akan berubah menjadi pucat dan mengalami perubahan ukuran menjadi besar apabila ginjal terpapar dengan zat yang bersifat nefrotoksik. 


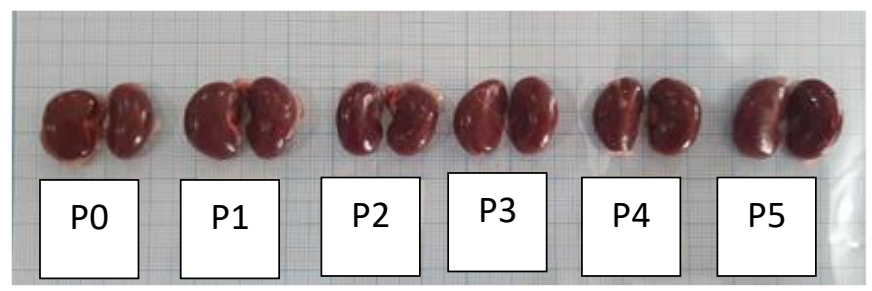

Gambar 1. Perbandingan makroskopis ginjal

Tabel 1. Uji ANOVA konsumsi air minum, bobot ginjal, lebar ruang kapsula bowman, tebal sel epitel tubulus proksimal dan tebal sel tubulus distal serta Uji kruskal wallis diameter glomerulus.

\begin{tabular}{ccccccc}
\hline & \multicolumn{5}{c}{ Parameter } \\
\cline { 2 - 7 } Perlakuan & $\begin{array}{c}\text { Konsumsi } \\
\text { Air Minum } \\
(\mathrm{ml})(\mathrm{Mean} \\
\pm \text { SD) }\end{array}$ & $\begin{array}{c}\text { Bobot } \\
\text { Ginjal }(\mathrm{g}) \\
(\text { Mean } \pm \\
\text { SD) }\end{array}$ & $\begin{array}{c}\text { Diameter } \\
\text { Glomerulus } \\
(\mu \mathrm{m})(\mathrm{Mean} \\
\pm \text { SD) }\end{array}$ & $\begin{array}{c}\text { Lebar Ruang } \\
\text { Kapsula } \\
\text { Bowman }(\mu \mathrm{m}) \\
(\text { Mean } \pm \text { SD) }\end{array}$ & $\begin{array}{c}\text { Tebal Sel } \\
\text { Epitel } \\
\text { Tubulus } \\
\text { Proksimal } \\
(\mu \mathrm{m})(\text { Mean } \\
\pm \text { SD) }\end{array}$ & $\begin{array}{c}\text { Tebal Sel } \\
\text { Epitel Tubulus } \\
\text { Distal }(\mu \mathrm{m})\end{array}$ \\
\hline P0 & $26,95 \pm 1,59$ & $0,77 \pm 0,45$ & $76,61 \pm 4,89$ & $11,03 \pm 1.36$ & $11.66 \pm 0,82$ & $9,07 \pm 0,75$ \\
P1 & $68,75 \pm 36,04$ & $0,98 \pm 0,16$ & $77,16 \pm 5,94$ & $11,46 \pm 1.23$ & $11,39 \pm 0,65$ & $9,29 \pm 0,54$ \\
P2 & $70,53 \pm 36,60$ & $0,95 \pm 0,23$ & $79,51 \pm 4,35$ & $10.68 \pm 0,95$ & $12,43 \pm 0,09$ & $9,04 \pm 0,95$ \\
P3 & $70,32 \pm 33.91$ & $0,84 \pm 0,07$ & $82,71 \pm 8,01$ & $8,69 \pm 1,18$ & $11,57 \pm 0,42$ & $8,33 \pm 0,70$ \\
P4 & $80,03 \pm 4,20$ & $0,89 \pm 0,06$ & $79,19 \pm 1,52$ & $9.48 \pm 0.40$ & $11,56 \pm 0,52$ & $9,62 \pm 0,15$ \\
P5 & $61,24 \pm 34,73$ & $0,89 \pm 0,19$ & $77.95 \pm 3.56$ & $10.60 \pm 0.72$ & $11,78 \pm 0,56$ & $9,35 \pm 0,62$
\end{tabular}

Keterangan: Data yang ditampilkan adalah data rerata dan standar deviasi. P0 (tikus normal dan tidak diberi ekstrak etanol daun mimba). P1 (Tikus hiperglikemia diberi dengan aquades). P2 (Tikus hiperglikemia diberi dengan ekstrak). P3, P4, dan P5 secara berturut-turut adalah tikus hiperglikemia yang diberi ekstrak etanol daun mimba (Azadirachta indica A.Juss) dengan dosis $100 \mathrm{mg} / \mathrm{kgBB}, 200 \mathrm{mg} / \mathrm{kgBB}$, dan 400 $\mathrm{mg} / \mathrm{kgBB}$.

Hasil uji Analisys of Variance (ANOVA) data rata-rata konsumsi air minum harian pada masing-masing perlakuan menunjukkan hasil yang berbeda tidak nyata. Hal ini berarti bahwa pemberian ekstrak etanol daun mimba tidak memberikan pengaruh terhadap konsumsi air minum tikus putih hiperglikemia. Rata-rata hasil pengukuran konsumsi air minum dapat dilihat pada Tabel 1. menunjukkan bahwa kelompok P0 menunjukkan angka rata-rata paling kecil dibanding dengan kelompok P1, P2, P3, P4, dan P5. Perlakuan P5 menunjukkan adanya penurunan konsumsi air minum jika dibandingkan dengan kelompok P1, P2, P3, dan P4. Nugroho (2012) menyatakan bahwa polidipsia disebabkan oleh poliuria yang menjadi gejala awal pada penderita diabetes. Saat kondisi hiperglikemia, maka tubuh akan mengeluarkan glukosa berlebih melalui air kemih. Keadaan poliuria akan mengakibatkan tubuh dehidrasi karena terus menghasilkan kemih dalam jumlah berlebih sehingga muncul gejala polydipsia karena tubuh sering merasa haus yang akan mengakibatkan peningkatan konsumsi air minum.

Hasil uji Analysis of Variance (ANOVA) bobot ginjal pada masing-masing perlakuan memberikan hasil berbeda tidak nyata. Hal ini berarti bahwa pemberian ekstrak etanol daun mimba tidak memberikan pengaruh terhadap ratarata bobot ginjal tikus. Tabel 1. menunjukkan bahwa kelompok P0 adalah ginjal dengan bobot yang paling kecil jika dibanding dengan perlakuan 
yang lainnya. P1 adalah bobot ginjal yang paling tinggi. P2, P3, P4, dan P5 memiliki rata-rata bobot ginjal yang lebih rendah jika dibandingkan P1. Penelitian yang dilakukan oleh Christian et al. (2020) menunjukkan bahwa induksi diabetes dapat meningkatkan bobot dari ginjal jika dibandingkan dengan kontrol non diabetes. Anindita (2019) menyatakan bahwa bobot ginjal dapat dijadikan parameter adanya perubahan fungsi pada ginjal. Perubahan bobot ginjal berkaitan dengan berbagai komponen seluler yang berperan dalam proses ekskresi dan eliminasi metabolit tubuh. Perubahan bobot ginjal disebabkan oleh kerusakan komponen seluler yang berdampak pada perubahan fungsi ginjal.

Hasil analisis uji non parametrik Kruskalwallis diameter glomerulus pada masing-masing perlakuan memberikan hasil yang berbeda tidak nyata. Hal ini berarti bahwa berdasarkan analisis statistik pemberian ekstrak etanol daun mimba tidak memberikan pengaruh berbeda nyata terhadap perubahan ukuran diameter glomerulus ginjal. Kelompk perlakuan P0 memiliki diameter glomerulus paling kecil, kemudian diikuti oleh P1, P5, P4, P2, dan P3. Kelompok perlakuan P2, P3, dan P4 menunjukkan adanya hipertrofi glomerulus. Aloksan yang diinduksikan kepada tikus akan mengakibatkan kondisi hiperglikemia pada tikus yang selanjutnya akan berpengaruh terhadap struktur jaringan pada glomerulus. Kondisi hiperglikemia akan mengakibatkan hipertrofi glomerulus dikarenakan adanya tekanan terhadap sel-sel glomerulus. Penelitian yang dilakukan oleh Handani dkk. (2015) menunjukkan bahwa pada tikus yang diinduksi dengan aloksan akan menyebabkan pelebaran sel glomerulus yang mengakibatkan perlekatan antara glomerulus dengan kapsula bowman. Rao et al. (2011) menyatakan bahwa kadar glukosa darah yang tinggi dapat menyebabkan peningkatan tekanan terhadap sel mesangial sehingga mesangium glomerulus mengembang dan terjadi hipertrofi seluler yang mengakibatkan pelebaran sel glomerulus. Penelitian yang dilakukan oleh Septiva (2019) menyatakan bahwa pemberian ekstrak etanol daun mimba memberikan hasil yang berbeda bermakna terhadap diameter glomerulus ginjal mencit. Penambahan diameter glomerulus disebabkan karena adaptasi seluler yang diakibatkan oleh pemberian ekstrak etanol daun mimba Mayori (2013) menyatakan bahwa adaptasi sel berupa perbesaran ukuran sel disebabkan oleh peningkatan beban kerja suatu sel. Perbedaan antara glomerulus normal dan glomerulus yang mengalami hipertrofi pada masing-masing perlakuan dapat dilihat pada Gambar 2.

Hasil uji Analysis of Variance (ANOVA) data lebar ruang kapsula bowman pada masingmasing perlakuan memberikan hasil berbeda tidak nyata.. Hal ini berarti bahwa pemberian ekstrak etanol daun mimba tidak memberikan pengaruh terhadap perubahan lebar ruang kapsula bowman. Tabel 1. menunjukkan bahwa kelompok kontrol negatif (P1) memiliki rerata lebar ruang kapsula bowman yang lebih besar dari pada rerata kelompok kontrol normal (P0), selanjutnya kelompok kontrol positif (P2), P3, P4, dan P5 mengalami penurunan rerata lebar ruang kapsula bowman. Kelompok P2 dan P5 memiliki rerata angka ruang kapsula mendekati kolompok K0. Penyempitan dari ruang kapsula bowman diduga dikarenakan hipertrofi glomerulus yang disebabkan oleh keadaan hiperglikemia. Pelebaran dari ruang kapsula bowman diduga dikarenakan oleh banyaknya filtrat yang masuk ke dalam ruang kapsula dari glomerulus dikarenakan terjadi hiperfiltrasi ketika terdapat kadar gula darah yang berlebih. Penelitian yang dilakukan Wardani (2012) menunjukkan bahwa terjadi peningkatan filtrat yang masuk ke tubulus proksimal. Penelitian yang dilakukan oleh Sousa et al. (2020) menunjukkan bahwa pada tikus kontrol diabetes yang diberi larutan garam fisisologis menunjukkan perubahan pada histologi ginjal berupa glomerulonefritis dan sclerosis seperti pelebaran ruang kapsula bowman, hyaline arteriosclerosis, fibrosis, dan inflamasi. Penyempitan ruang kapsula bowman menurut Wardani (2012) disebutkan bahwa penyempitan jarak antara kapsula bowman dengan glomerulus dapat disebabkan oleh pembesaran glomerulus atau karena penyempitan dari kapsula bowman itu sendiri. Peningkatan volume glomerulus menandakan adanya perbesaran glomerulus (glomerulomegaly) yang dapat mengakibatkan penyempitan terhadap lebar 
ruang kapsula bowman (Herlitz et al., 2010). Perbedaan pelebaran dan penyempitan ruang kapsula bowman pada masing-masing perlakuan dapat dilihat pada Gambar 3.
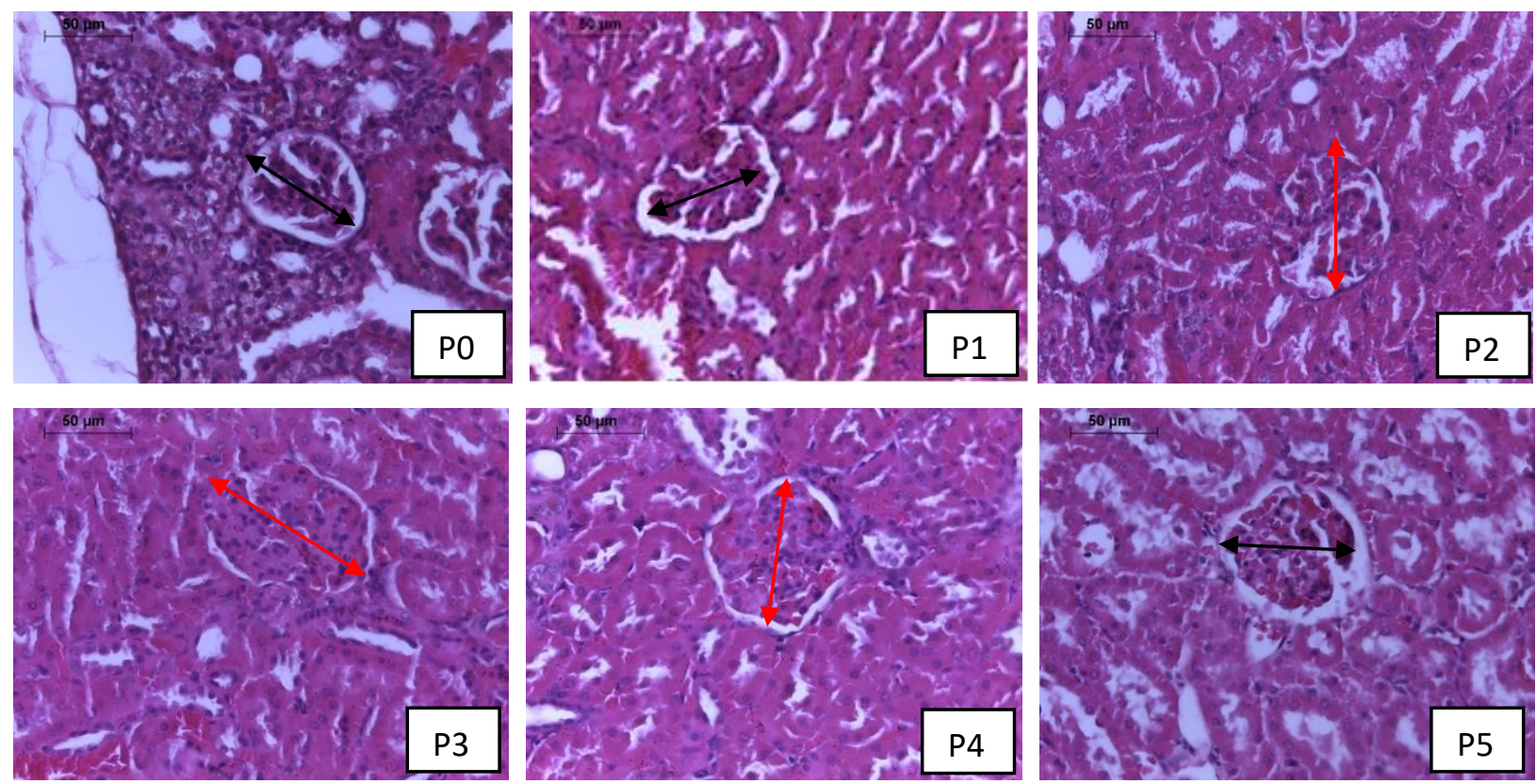

Gambar 2. Hasil pengamatan histologi diameter glomerulus ginjal pada setiap kelompok perlakuan (Pewarna HE; 400 kali). Keterangan: Garis panah hitam (glomerulus normal), garis panah merah (glomerulus hypertropi).
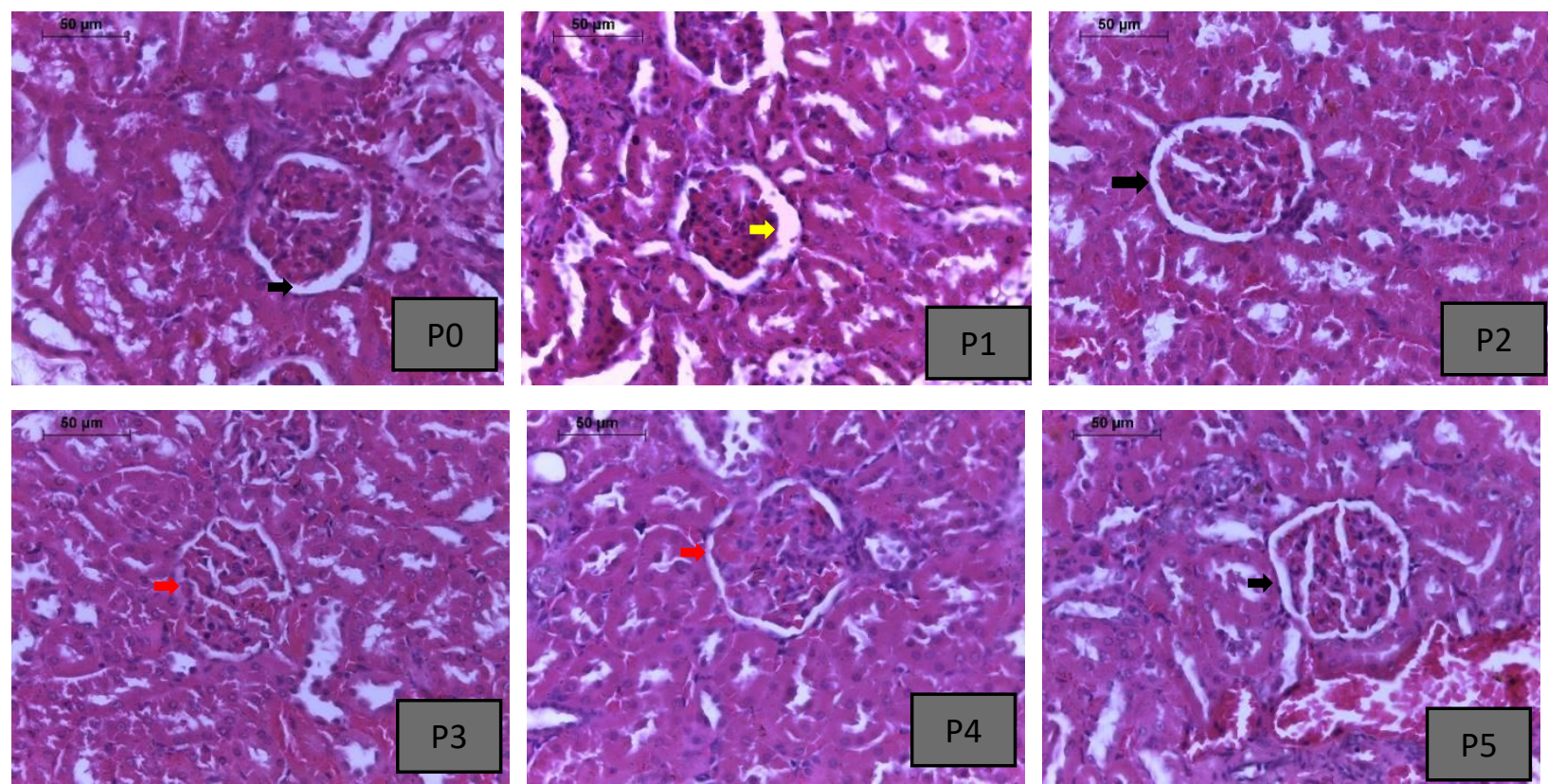

Gambar 3. Pengamatan histologi lebar ruang kapsula bowman pada tiap-tiap kelompok perlakuan (Pewarna HE; 400 kali). Keterangan: Anak panah hitam (ruang kapsula bowman normal), anak panah kuning (pelebaran ruang kapsula bowman), anak panah merah (penyempitan ruang kapsula bowman) 
Tubulus ginjal yang diamati pada penelitian kali ini (tubulus proksimal dan distal) tidak menunjukkan adanya perubahan ketebalan pada keduanya, namun dapat dilihat bahwa terjadi kematian sel (nekrosis) pada tubulus proksimal dan tubulus distal. Kematian diduga disebabkan oleh radikal bebas yang meningkat dikarenakan keadaan hiperglikemia oleh induksi aloksan. Meskipun demikian masih banyak sel yang berada dalam keadaan normal dan tidak mengalami kerusakan. Phaniendra et al. (2015) menyatakan bahwa radikal bebas merupakan atom atau molekul yang memiliki electron tidak berpasangan yang bersifat tidak stabil dan sangat reaktif untuk menarik electron molekul lain dalam tubuh guna mencapai keadaan stabil. Radikal bebas dapat merusak komponen biomolekul dengan cara merusak integritas lipid, protein, dan DNA, yang mengarah pada peningkatan stress oksidatif seperti penyakit neurodegenerative, diabetes mellitus, kardiovaskular, penuaan dini, dan kanker.

Hasil uji Analysis of Variance (ANOVA) data tebal sel epitel tubulus proksimal pada masing-masing perlakuan memberikan hasil berbeda tidak nyata. Hal ini berarti bahwa pemberian ekstrak etanol daun mimba tidak memberikan pengaruh terhadap ukuran sel tubulus proksimal. Berdasarkan Tabel 1. dapat dilihat bahwa semua perlakuan memiliki rerata tebal tubulus proksimal yang hampir sama pada tiap perlakuannya dan mendekati rerata kontrol normal. Hal ini menandakan bahwa keadaan hiperglikemia dan pemberian ekstrak etanol daun mimba tidak berpengaruh pada tebal sel epitel tubulus proksimal. Berbeda dengan hasil pengamatan sebelumnya pada glomerulus dan kapsula bowman yang memberikan perbedaan pada pengamatan histologis hal ini berkaitan dengan fungsi filtrasi pada glomerulus, sehingga lebih berefek pada glomerulus dan kapsula bowman jika dibandingkan dengan tubulus-tubulus pada ginjal dengan waktu paparan yang relative singkat. Kondisi Hiperglikemia pada tikus dengan lama penelitian selama 27 hari tidak memberikan efek terhadap tubulus proksimal. Hal ini sejalan dengan pernyataan Pourghasem et al. (2015) bahwa diabetic nephropathy jangka pendek akan menunjukkan hiperthrophy pada sel mesangial glomerulus. Perubahan awal yang terjadi pada jaringan ginjal adalah glomerular dan tubular hipertropi. Lesi pada glomerulus adalah perubahan yang paling signifikan pada kasus diabetic nefropathy. Penelitian yang dilakukan oleh Akinola and Zatta (2011) terjadi penebalan membrane basal pada sel tubular pada tikus diabetes selama 50 hari waktu penelitian. Gambar 4. menunjukkan bahwa tidak terdapat penebalan pada sel epitel tubulus proksimal di setiap perlakuan.

Hasil uji Analysis of Variance (ANOVA) data tebal sel epitel tubulus proksimal pada masing-masing perlakuan memberikan hasil berbeda tidak nyata.. Berdasarkan Tabel 1. dapat dilihat bahwa semua perlakuan memiliki rerata ukuran tubulus distal yang hampir sama pada tiap perlakuannya. Hal ini mengindikasikan bahwa baik pemberian aloksan maupun pemberian ekstrak etanol daun mimba belum memberikan efek kepada tebal tubulus distal. Hal ini menandakan bahwa keadaan hiperglikemia dan pemberian ekstrak etanol daun mimba selama 27 hari penelitian tidak berpengaruh pada tebal sel epitel tubulus proksimal. Berbeda dengan hasil pengamatan sebelumnya pada glomerulus dan kapsula bowman yang memberikan perbedaan pada pengamatan histologis hal ini berkaitan dengan fungsi filtrasi pada glomerulus, sehingga lebih berefek pada glomerulus dan kapsula bowman jika dibandingkan dengan tubulustubulus pada ginjal. Meeme and Kasozi (2009) menyatakan bahwa tingginya kadar glukosa dalam darah dapat menyebabkan terjadinya hiperfiltrasi pada glomerulus. Toneijck et al. (2017) menyatakan bahwa hiperfiltrasi yang disebabkan oleh diabetic nefropathy akan mengakibatkan kerusakan pada glomerulus berupa hypertrophy. Akinola and Zatta (2011) terjadi penebalan membrane basal pada sel tubular pada tikus diabetes selama 50 hari waktu penelitian. Toneijck et al. (2017) menyatakan bahwa diabetes dapat mengakibatkan hiperplasia dan hipertropi pada tubular. Gambar 5. menunjukkan bahwa tidak terdapat penebalan pada sel epitel tubulus proksimal di setiap perlakuan. 

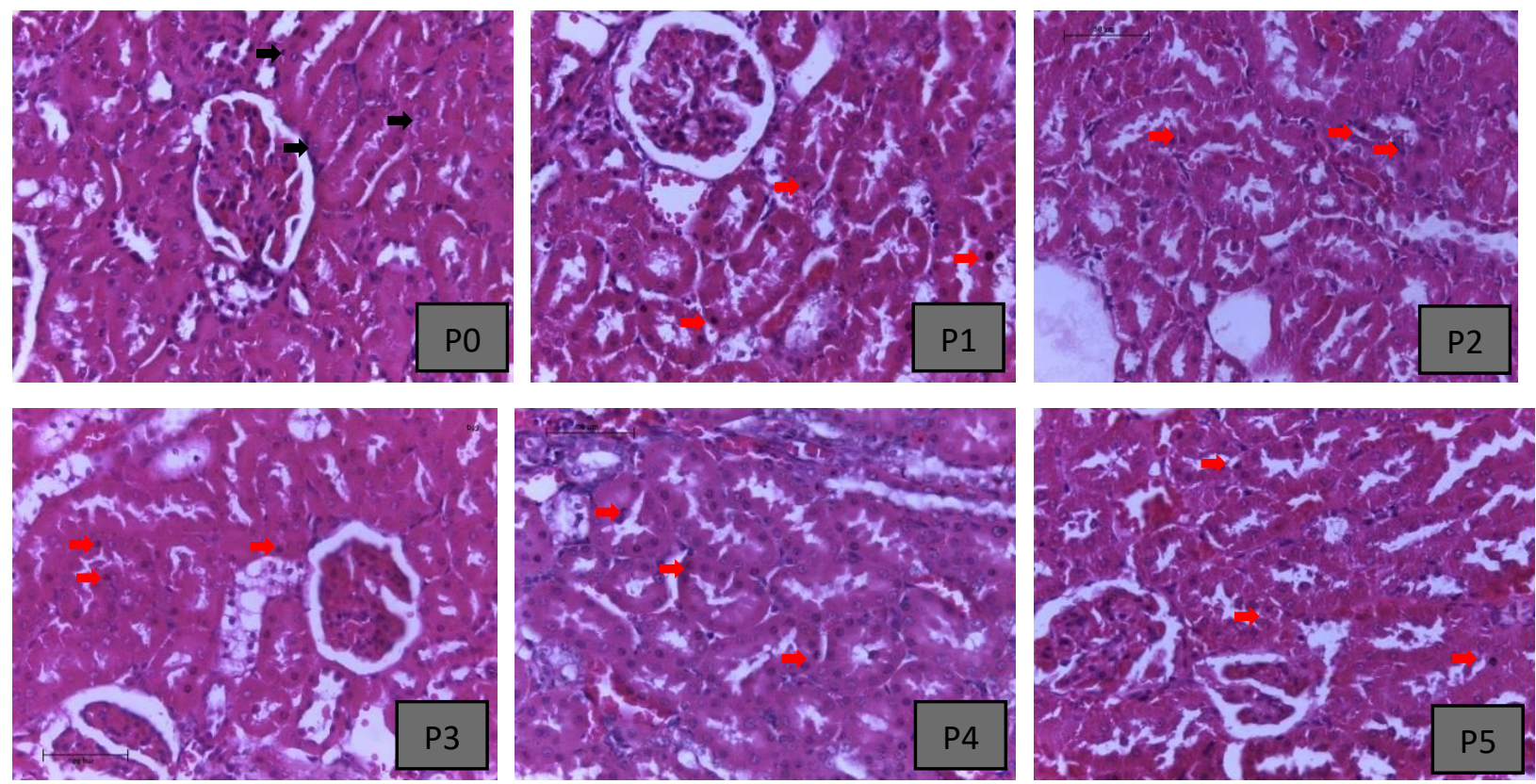

Gambar 4. Hasil pengamatan histologi tubulus proksimal pada setiap kelompok perlakuan (Pewarna HE; 400 kali). Keterangan: anak panah hitam (sel normal), anak panah merah (sel mengalami nekrosis).
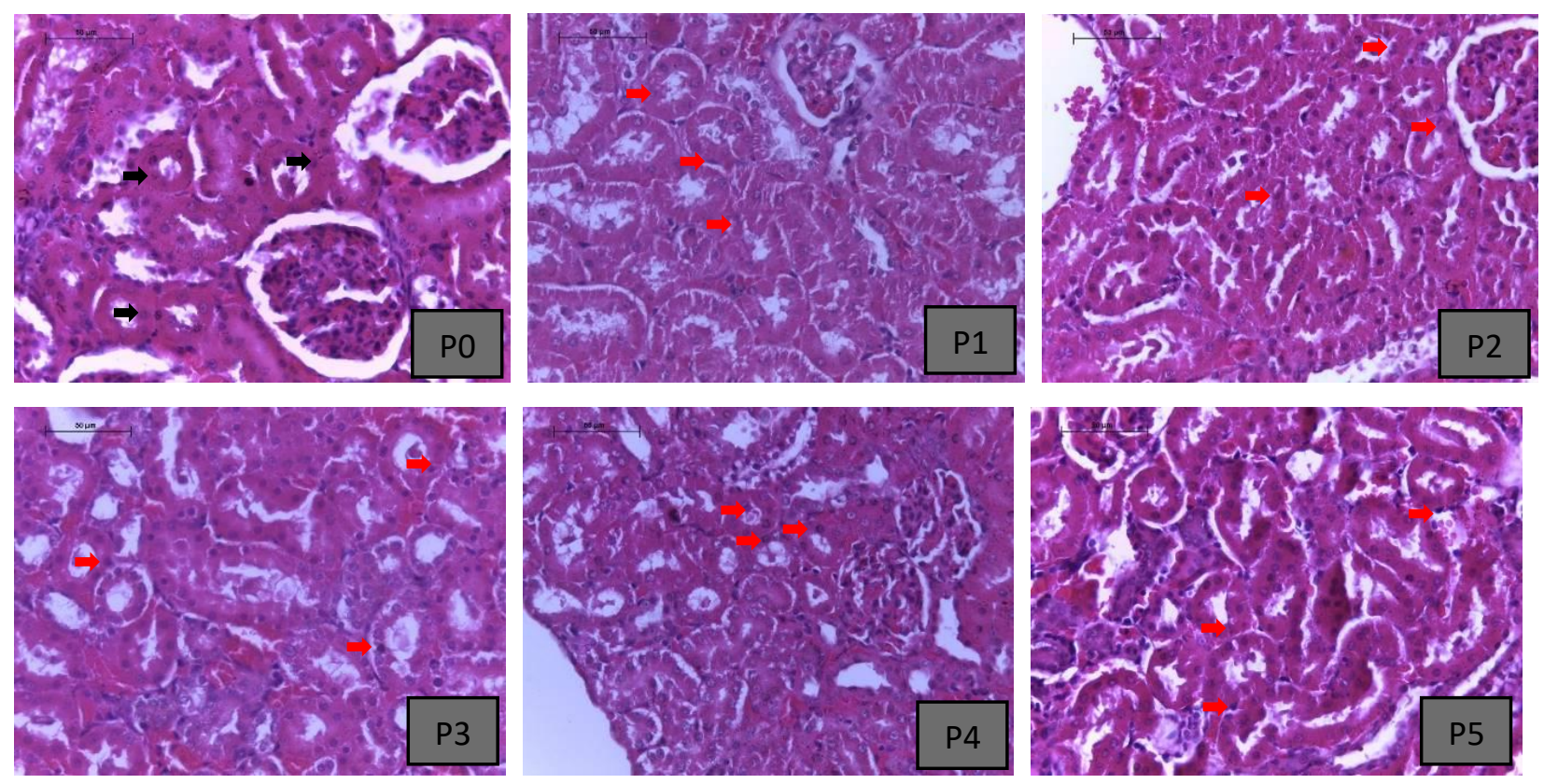

Gambar 5. Pengamatan Histologi tebal tubulus distal pada setiap kelompok perlakuan (Pewarna HE: 400 kali). Keterangan: anak panah hitam (sel normal), anak panah merah (sel mengalami nekrosis).

Mimba telah diketahui mengandung senyawa antioksidan flavonoid yang mampu melindungi jaringan yang rusak akibat paparan radikal bebas. Flavonoid lebih khususnya quercetin dapat bersifat antioksidan dengan mencegah stress oksidatif yang diinduksi oleh diabetes dan kerusakan DNA yang berkaitan dengan penurunan kadar nitric oxide synthase (NOS) di jaringan ginjal (Jiang Shi et al., 2019).

\section{KESIMPULAN}

Berdasarkan hasil penelitian ini dapat disimpulkan bahwa pemberian ekstrak etanol daun mimba (Azadirachta indica A.Juss) mampu 
melindungi jaringan ginjal tikus putih dari paparan hiperglikemia.

\section{UCAPAN TERIMAKASIH}

Penulis mengucapkan terimakasih sebesarbesarnya kepada Fakultas Sains dan Matematika Universitas Diponegoro yang telah membiayai penelitian ini dengan dana DIPA Fakultas Sains dan Matematika Universitas Diponegoro Nomor: 1970/UN.7.5.8/PP/2020.

\section{DAFTAR PUSTAKA}

Akinola, O.B., \& L. Zatta. 2011. Ameliorative Effects of Ethanolic LeafExtract of Azadirachta indicaonRenal Histologic Alterations inStreptozotocin-Induced Diabetic Rats. The American Journal of Chinese Medicine.39(5):903-916. DOI: 10.1142/S0192415X11009299.

Anindita, R. 2019. Uji Seduhan Daun Teh Hijau ( Camelia sinensis L). Pada Ginjal Mencit yang Diberi Monosodium Glutamat (MSG). Borneo Journal of Phamascientech. 3 (2):189-200

Arini, W., S. Isdadiyanto, \& A.J. Sitasiwi. 2020. Efek Pemberian Ekstrak Etanol Daun Mimba (Azadirachta indica A. Juss.) terhadap Struktur Ren Tikus Putih (Rattus norvegicus L.) yang Diberi Pakan Tinggi Lemak. Buletin Anatomi dan Fisiologi. 5(2):157-165. DOI: https://doi.org/10.14710/baf.5.2.2020.157-165

Aslam, F., K. Rehman, M. Asghar, \& M. Sarwar. 2009. Antibacterial Activity of Various Phytoconstituents of Neem. Pakistan Journal Agricultural Science. 46: 3-6.

Bandyopadhyay, U., K. Biswas, R. Chatterjee, D. Bandyopadhyay, I. Chattopadhyay, C. K. Ganguly, T. Chakraborty, K. Bhattacharya, \& R. K. Banerjee. 2002. Gastroprotective effect of Neem (Azadirachta indica) bark extract: possible involvement of $\mathrm{H}(+)-$ $\mathrm{K}(+)$-ATPase inhibition and scavenging of hydroxyl radical. Life Sci., 71(24): 28452865 DOI: https://doi.org/10.1016/s00243205(02)02143-4

Chong, W. C., R. Wu, \& Y. Cu. 2012. A Study on Tissue Processing. International Journal of Innovative Interdisciplinary Research. 3 (1): 37-43.

Christian, E.O., \& E. F. Chuckwuemeka. 2019. Antidiabetic and Modulatory Effect of
Ethanol Extract of Neem Leaf on Some Essential Biochemical Parameters of Streptozotocin-induced Diabetic Rats. International Journal of Biochemistry Research \& Review. 28(4): 1-11. DOI: https://doi.org/10.9734/ijbcrr/2019/v28i43015 7

Ezz-Din, D., M. S. Gabry, A. R. H. Farrag, \& A. E. A. Moneim. 2011. Physiological And Histological Impact Of Azadirachta Indica (Neem) Leaves Extract In A Rat Model Of Cisplatin-Induced Hepato And Nephrotoxicity. Journal of medical plants research. 5(23): 5499-5506. DOI: https://doi.org/10.5897/JMPR.9000980

Handani, A.E., M.N. Salim, A. Haris, H. Budiman, Zainudin, \& Sugito. Pengaruh Pemberian Kacang Panjang (Vigna unguiculata) Terhadap Struktur Mikroskopis Ginjal Mencit (Mus musculus) Yang Diinduksi Aloksan. Jurnal Medika Veterinaria. 9(1):18-22. DOI: https://doi.org/10.21157/j.med.vet..v9i1.2987

Herlitz, L.C., G.S. Markowitz, A,B. Farriz, J.A. Schwimmer, M.B. Stokes, C. Kunis, R.B. Colvin, \& V.D. D'Agati. 2010. Development of volcal segmental of glomerulosclerosis after Anabolic Steroid Abuse. Journal of the American Society of Nephrology. 21: 163172. DOI: 10.1681/ASN.2009040450.

Jiang shi, G., Y. Li, Q. H. Cao, H. X. Wu, X. Y. Tang, X. H. Gao, J. Q. Yu, Z. Chen, and Y. Yang. 2019. In Vitro And In Vivo Evidence That Quercetin Protects Against Diabetes And Itscomplications: Asystematic Review Of The Literature. Biomedicine dan Pharmacotheraphy. 109 : 1085- 1099. DOI: https://doi.org/10.1016/j.biopha.2018.10.130

Kemenkes RI. 2014. InfoDATIN : Situasi dan Analisis Diabetes Melitus. Pusat Data dan Informasi Kementrian Kesehatan Republik Indonesia, Jakarta.

Mayori R, N Marusin, \& D. H. Tjong. 2013. Pengaruh pemberian Rhodamin B terhadap struktur histologis ginjal mencit putih (Mus musculus L.). Jurnal Biologi Universitas Andalas, $\quad 2(1)$ : $\quad 1-7 . \quad$ DOI: https://doi.org/10.25077/jbioua.2.1.\%25p.201 3

Meeme, A., \& H. Kasozi. 2009. Effect of glycaemic control on glomerular filtration rate in Diabetes Mellitus patients. African Health Sciences. 1 (9): 23-26.

Nugroho, S. 2012. Pencegahan dan Pengendalian Diabetes Melitus Melalui Olahraga. Jurnal 
Ilmiah Kesehatan Olahraga. 9 (1): 1-15. DOI: https://doi.org/10.21831/medikora.v0i1.4640

Phaniendra, A., Jestadi, D. B. \& Periyasamy, L., 2015. Free Radicals: Properties, Sources, Targets, and Their Implication in Various Diseases. Indian J Clin Biochem, 30(1): 1126. DOI: $10.1007 / \mathrm{s} 12291-014-0446-0$

Petrie, J. R., J.T. Ghuzik, \& R. M. Touys. 2017. Diabetes, Hypertension, and Cardiovascular Disease: Clinical Insight and Vascular Mechanisms. Can J Cardiol. 34(5):575-584. DOI: 10.1016/j.cjca.2017.12.005.

Pourghasem, M., E. Nasiri, \& H. Shafi. 2014. Early Renal Histological Changes in AlloxanInduced Diabetic Rats. International Journal of Molecular and Cellular Medicine. 3:11-15

Rao, P.T., K.S. Rao, \& C.L. Usha. 2011. Stochastic Modeling Of Blood Glucose Level In Type-2 Diabetes Mellitus. Asian J. Math. Stat. 4(1):56-65. DOI: http://dx.doi.org/10.3923/ajms.2011.56.65

Septiva, E. B., A.J. Sitasiwi, \& S. Isdadiyanto. 2019. Struktur Mikroanatomi Ginjal Mencit (Mus musculus L.) Betina Setelah Paparan Ekstrak Etanol Daun Mimba (Azadirachta indica A. Juss). Jurnal Pro-Life. 6(2): 180190

Sousa, L.G.F., L.U.A.S. Cortez., J.S.A.M. Evangelista., F.A.F.X., Junior., D.B. Heimark., M.C., Fonteles., C.F., Santos, \& N.R.F. Nascimento. 2020. Renal Protective effect of pinitol in experimental diabetes. European Jurnal of Pharmacology. 880: 1-10. DOI:

https://doi.org/10.1016/j.ejphar.2020.173130

Sugiarta, I. G. R., \& I. G. K. Darmita. 2020. Profil Penderita Diabetes Mellitus Tipe-2 (DM-2) dengan Komplikasi yang Menjalani Rawat Ianp di RFumah Sakit Umum Daerah (RSUD) Klungkung Bali tahun 2018. Instisari Sains Medis . 11 (1): 7-12. DOI: https://dx.doi.org/10.15562/ism.v11i1.515

Tonneijck, L., M.H.A. Muskiet, M.M. Smits, E.J.V. Bommel, H.J.L. Heerspink, D.H.V. Raalte, \& J.A. Joles. 2017. Glomerular Hyperfiltration in Diabetes: Mechanism, Clinical Significance and Treatment. $J A m$ Soc Nephrol. 28 (4): 1023-1039. DOI: 10.1681/ASN.2016060666.

Vessal M, M. Hemmati, \& M. Vasei. 2003. Antidiabetic Effects Of Quercetin In Streptozocin Induced Diabetic Rats. Comp. Biochem. Physiol. C., 135: 357-364. DOI: 10.1016/s1532-0456(03)00140-6
Wardani, G.T. 2012. Kajian histopatologis pengaruh vaksin Streptococcus Agalactiae yang diradiasi pada organ hati dan ginjal mencit (Mus Musculus). Skripsi. Fakultas Kedokteran Hewan Institiut Pertanian Bogor. 